Charlotte Haug (f. 1959) er dr.med. og har en mastergrad i helsetjenesteforskning fra Stanford University. Hun har vært redaktør av Tidsskrift for

Den norske legeforening siden 2002.

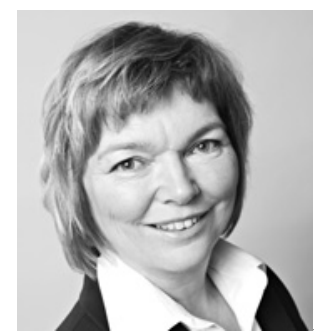

Foto Einar Nilsen

\section{Et moralsk spørsmål}

«For første gang diskuterer norske myndigheter om barn skal måtte betale egenandel for vaksiner på helsestasjonen. Skam!» skrev Preben Aavitsland på nettsamfunnet Twitter 1.6. 2012 (1). Bakgrunnen var at Nasjonalt råd for kvalitet og prioritering i sitt møte 4.6. skulle drøfte om rotavirusvaksine skulle bli del av det norske barnevaksinasjonsprogrammet (2). Vaksinen er - som de fleste nye legemidler - kostbar. Sykdommen den skal forhindre er plagsom, men ikke veldig alvorlig, og den er over i løpet av noen dager. Nesten alle barn blir smittet av rotavirus før de har fylt fem år, og mange blir syke. Totalt sett blir det mange fraværsdager for foreldre og dermed store kostnader for samfunnet og arbeidsgiverne. Det saken dreier seg om, er å veie ulempen ved at barn blir syke med oppkast og diaré noen få dager - enkelte med et sykehusopphold - mot kostnaden i kroner og helsestasjonsressurser ved å vaksinere samtlige norske spedbarn. Det er ubehagelig med diaré og oppkast, men fordi fordelen ved vaksinen først og fremst er mindre fravær fra arbeidet for omsorgspersonene, krever noen land som har innført vaksinen en egenandel av foreldrene. Man kan også tenke seg at arbeidsgiver ville betale eller subsidiere vaksinen, slik mange gjør når det gjelder influensavaksine. Dette var blant temaene enkelte i prioriteringsrådet ønsket å diskutere. En slik diskusjon syntes altså Aavitsland var skammelig.

Preben Aavitsland gikk av som assisterende divisjonsdirektør ved Nasjonalt folkehelseinstitutt i februar 2012 etter å ha arbeidet der i en årrekke med smittevern og vaksiner. Nå er han en av tre som ønsker å overta direktørstillingen etter Geir Stene Larsen, som nylig ble utnevnt til ekspedisjonssjef i folkehelseavdelingen i Helse- og omsorgsdepartementet. Folkehelseinstituttets anbefaling er at rotavirusvaksinen tas inn i barnevaksinasjonsprogrammet. At Aavitsland kjemper for at dette skal få gjennomslag, er derfor verken overraskende eller problematisk. Men hvorfor mener han det er en skam å drøfte ulike alternativer for finansiering av vaksinen?

I Tidsskriftet nr. 9/2012 skrev jeg om private helseforsikringer (3). At en stadig økende andel av befolkningen tegner slike, er en realitet. At det er en rekke problematiske sider knyttet til dette, er selvsagt $(4,5)$. Ikke minst bryter det med vårt norske likhetsideal, for i forsikringsverdenen er noen likere enn andre. Ikke hvem som helst får anledning til å tegne privat helseforsikring. Man skal for eksempel helst være frisk og ikke ha kjente risikofaktorer for sykdom. Det er bare slik forsikringsselskapene kan tjene penger - altså ved å overbevise folk om at de har større risiko for en fremtidig uheldig hendelse (f.eks. alvorlig sykdom) enn de reelt sett har, slik at de er villig til å betale en forsikringspremie som over tid er høyere enn forsikringsselskapenes utbetalinger. De som virkelig trenger forsikring, får det ikke, de som ikke har så stort behov, får. Det er ikke rettferdig. Når jeg likevel tok til orde for at vi burde løfte debatten om private helseforsikringer ut av tabusonen, var det for å fremheve at betaling for helse- og omsorgstjenester allerede eksisterer i stor skala og at det etter mitt skjønn er bedre å diskutere åpent hvordan privat medfinansiering kan skje enn å lukke øynene og late som ingenting. Mange ønsket debatten velkommen, andre ga uttrykk for at bare det å reise spørsmålet kunne være med på å undergrave det offentlige helsevesenet. Ingen har gått så langt som å si at jeg burde skamme meg, men undertonen er at det er noe nesten uanstendig ved å antyde at ett alternativ til ikke å tilby en offentlig tjeneste i det hele tatt, er at den kan gis til dem som vil bidra fra egen lommebok.

Vi forteller stolt at vårt helsevesen og våre velferdsordninger er likt og rettferdig fordelt og at de som trenger hjelp, får etter behov og ikke etter størrelsen på lommeboken. Men er det slik? Vi har for eksempel en sykelønnsordning som arbeidstakere i mange land misunner oss: Full lønn ved sykdom fra første dag - ingen skal straffes økonomisk for å være syk. Det er flott! Det er vanskeligere å forklare for utenforstående hvorfor dette prinsippet bare gjelder i ett år og bare hvis du er i arbeid når du blir syk. Hvis du er alvorlig og langvarig syk, fratas du sykepengene etter ett år i Norge. Er du ikke i arbeid når du blir syk, får du ikke sykepenger. Det er heller ikke så lett å forklare hvorfor vi har valgt å la problemer med syn og tenner behandles særskilt. I de fleste land oppfattes tannlegetjenester og tilpasning av briller som en selvsagt del av det samlede offentlige helsetjenestetilbudet.

Det norske helsevesenet har mange svært gode sider, men også betydelige problemer med å få gjort alt som burde og kunne gjøres for pasientene. Det er lite sannsynlig at det er mulig å dekke ressursbehovet fullt ut gjennom økte skatter og overføringer fra det offentlige. Det er også slik at befolkningen har ulike preferanser når det gjelder hva slags helsetjenester de ønsker å få fullt ut dekket av det offentlige. Særlig gjelder det mindre alvorlige sykdommer som for eksempel rotavirusinfeksjon. Noen foreldre og arbeidsgivere vil synes det er greit å gi barnet vaksine for å minske risikoen for diaré, oppkast og foresattes sykefravær. Andre vil foretrekke at helsesøsters tid brukes til andre oppgaver.

Prioriteringsrådet diskuterte rotavirusvaksinen i flere timer på sitt møte. De anbefalte at den ikke skulle tas inn i barnevaksinasjonsprogrammet. De ville heller legge til rette for at de som ønsker vaksinen, skal kunne få den på annen måte $(2,6)$. Det er flott at vi har et prioriteringsråd som kan si nei og som er villig til å ta de vanskelige, men nødvendige debattene.

\footnotetext{
Litteratur

1. https://twitter.com/Epidemino/status/208483694565007360 (5.6.2012)

2. www.kvalitetogprioritering.no/Cases+by+year/Innføring+av+vaksine+mot+ rotavirusinfeksjon.14351.cms (5.6.2012).

3. Haug C. Med hodet i sanden kommer vi ingen vei. Tidsskr Nor Legeforen 2012; 132: 1057.

. Haug C. Helseministerens forsikringer. Tidsskr Nor Lægeforen 2002; 122: 2689.

5. Haug C. Med liten skrift. Tidsskr Nor Lægeforen 2003; 123: 2007.

6. Dommerud T. Nei til omgangsykevaksine. Aftenposten morgenutgave 5.6.2012.
} 